\title{
エンタテイメントシステム
}

\section{Entertainment Systems}

\author{
白井 暁彦 \\ Akihiko Shirai ${ }^{\dagger}$ \\ 東京工業大学 精密工学研究所 ${ }^{\dagger}$ \\ Precision and Intelligence Laboratory, Tokyo Institute of Technology ${ }^{\dagger}$ \\ 干 226-8503 神奈川県横浜市緑区長津田町 4259 \\ 4259, Nagatsuta, Midori-ku, Yokohama, Kanagawa, 226-8503, Japan \\ E-mail : shirai@mail.com \\ この論文は , 近年のコンピュータゲームに代表されるエンタテイメントシステムの定義に関す \\ る論文である.芸術科学分野において, エンタテイメントシステムは, メディアアートやテク \\ ノロジアートといった他のインタラクティブシステムと混同され，もしくは关の解釈をあいま \\ いにして語られることが多い. 本論文では中世から近代, 現代の「遊び」に関する科学的研究 \\ を引用しつつ, 近年のコンピュータを用いた遊びのためのシステムである「エンタテイメント \\ システム」の解説と定義を, 最新の実例とともに行うものである .
}

概要

Abstract

This paper describes a definition of entertainment systems that is represented by computer games. In Art and Science fields, entertainment systems often are sorted such media or technology arts with a confusion. In other cases, they are discussed under unclear interpretation. In this paper, it has referred to previous scientific studies of 'human plays' for Middle Ages to Present Days that explains and defines about 'entertainment systems' like current computer games such using computer for playing with latest examples.

キーワードエンタテイメントシステム，コンピュータゲーム，定義，歴史

Keyword entertainment systems, computer games, definition, history 


\section{1 はじめに}

現存する旧石器人の絵画のひとつであるフランス・ ラスコー洞窟の壁画には, オーロックス (原牛) やウ マ, カモシカなどの図画や, 最近では動物に模した星 座や月の位置といった彩色図画が発見されている [1] . 1 万 6500 年ほど前の水河期に描かれたこの壁画は, 絵 を描き残すという古の人類による artであると同時に， 狩猟の方法や暦といった技術の記録という意味でとら えれば, 現存する旧石器人類の engineering の一端で あるともいえる ${ }^{1}$.この壁画を描いた人物が，当時ど のような目的で，この著作を壁面に残したのかの解明 は想像の域を出ないが，少なくとも，当時の人類が， 狩猟や捕食といった生命の維持に直接関係した行動だ けではなく、遊び」や「楽しみ」, 芸術活動といった 要素が含まれる，一見すると不可解な行動をとってい た点に関しては事実といえよう.

本論文は, エンタテイメントシステムについて述べ るものである.しかしながら, 近年のエンタテイメン トシステムについて解説する前に, まず「遊び」の科 学的研究について解説したい.中世から近代, 現代の 「遊び」に関する科学的研究を紐解くと「遊び」を科 学的に扱う上での危険性や, コンピュータやデバイス を用いたシステムを構筑する上での留意すべき点が明 確になってくるからである．また，曖昧にされがちな メディアアートやテクノロジアートといった他の芸術 性を持ったインタラクティブシステムとの境界も明確 になる 。

\section{2 「遊び」の科学的研究とその歴史}

「遊び」について注目した研究の歴史は長い，光の

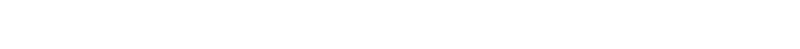
まず「人間はなぜ斿ゔのか」「なぜ面白いと感じるの か」といった源流や遊びの理論に関する研究 (古典的 遊ひ論)，次に「光の遊びはどのような種類のものであ るか」という分類 (近代的遊ひ論), さらに, 実際の遊 びの樣子を観察し, 行動から分類, 動機, 発達に結び つける研究である.これらは近代から現代にかけて， 時代や科学の発展において「人間とは何か」といった 研究とともに，常に問い掛けられてきた。発端は哲学， 心理学, 生理学であつたが, 弚の後, より掘り下げら れ, 文化学, 言語学, 教育学, 民俗学といった人文社 会科学への影響を強く与えるとともに, 発達心理学や 児童心理学をはじめとする心理学の基盤構築に大きく 寄与してきた 。

\section{1 「遊び」の研究の源流}

ロシアの児童心理学の指導者エリコニン (Э л ь к о н и н , Д. Б .,1904-1984) は著書『遊びの心理学』 (原著 1978 年) の中で、遊び」に関する理論的研究と 光の源流について，心理学者の見地から以下のように

\footnotetext{
1 近年, 仏南西部キュサックの洞窟 (2000 年) や, 仏南東部ショー べ洞窟 (1994 年) で発見された線刻画が, 放射線微粒子加速装置に よる鑑定で約 3 万年前とされており，“人類最古の図画”ではなく なった [2].
}

まとめている $[3]$.

遊びの理論的研究の始まりは, F. シラー, H. スペ ンサー ,W. ヴントといった 19 世紀の思想家の名前と 結びついている.ただし，この時代の研究は，自己の 哲学的見解, 心理学的見解, 主として美学の見解を作 り上げる際に, 最も広くいきわたっている生活現象の ひとつとして遊びにも触れ, 兴の際に, 遊びの発生と 芸術の発生を関連付けたものが多い.

例えば，F. シラー (Friedrich von Schiller, 17591805 , ドイツの詩人, 戯曲家 .ゲーテとともにドイツ古 典主義) は , 人間の美の教育に関する手紙の中で「ラ イオンが空腹でなく，猛獣が戦いを挑まないときには， 余った力兴のものが自ら自己目的となる.ライオンは， 荒野を力強い吼え声で満たし, 有り余る力は目的のな い消費によって，自らを楽しませる (略)」と記してい る.これは「余剩エネルギ一説」と呼ばれる「遊びの源 流」に関する主要な理論である . シラーにとって遊び は美的活動であり，外的必要性から切り離された「余 剰のエネルギー」は美的楽しみが発生するための条件 でしかない.また产の美的楽しみは遊ぶことによって のみ得られるとされ，遊びを含めた美的活動への動機 として一般化されている.この 16 世紀のシラーによ る余乘説は「遊び」の自己目的性や非生産性を鋭く指 摘しており，後世にわたって引用される .

H. スペンサー (Herbert Spencer, 1820-1903,イギリ スの社会学者, 社会を生物と同じような有機体である と考える社会有機体説が有名) は 1897 年に, シラーの 余剩エネルギー説をより広い進化論的生物学の文脈の 中で問題にし，遊びは「まさに人工的な練習である」 としている「自然に行われる練習ではエネルギーがあ まる結果, 発散の準備をし, 虚構活動の中で不十分な 実際の活動の場への出口を探す」とし, 美的活動と遊 びの違いは,「遊びには，より低い資質か現れることの み」であるとしている .

また W. ヴント (Wilhelm Wundt, 1832-1920, 心理 学を哲学から独立した学問へと導いた近代心理学の 祖の 1 人，世界で最初の心理学実験室を開設した) は 1887 年に「遊びは子供の労働である」とし, 遊びを社 会歴史的見地に含めた .これらの源流諸説は体系的遊 びの理論といった視点の研究ではなく, 美的活動の発 生という文脈の中で, 遊びの本性を検討している .

古典的遊ひ論は「余剩エネルギー説」の他にも，労 働によって蓄積された疲労と緊張をレクリエーション によって除去する「気晴らし説」, 遊びは本能の産物 であり, 成長後の生活に欠かせない行動獲得であると する「本能的生活準備説」, 行動的な進化の鏡, すな わち遊びは系統発生的連続を個体発生的にリハーサル しているという「反復説」などか論じられている.こ の時期の特徵としては, 生物学的知見を基盤としてお り「遊び」を行う当の本人にとって「遊びが何を意味 しているか」は問わず，光の役立つ目的を二次的に論 及したにすぎないが，人間個人の内部に「遊ぶ精神」 と考えられるエネルギーが内在することや，遊びが持 つ客観的な構造が歴史的に受け継がれていることを指 摘するなど , 素朴に見える遊戯行動が以下に多くの観 点から論ずることが可能かを示した時期であるとも言 える。

近代的遊び論では「遊びの因果関係を踏まえて前後 
の出来事をつなぐ試み」が特徵付けられる．人間性を 回復補充するために行われるとする K. ランゲの「補 充説」, フラストレーションや攻撃性を取り払うと強 調した H.A. カー, S. ミラーらの「カタルシス (浄化, 排泄) 説」, 日常生活とは別に自己表現を可能にする 活動を求める E.D. ミッチェル, B.S メーソンらの「自 己表現説」がある . [4, 14]

\section{$2.2 \Gamma$ 遊び」の分類}

近代から現代への遊び論への転換は, 文化の基礎と しての遊びを論じたホイジンガ, 社会や文化の指標と して遊びを捉えようとしたカイヨワの両者が , 現在の 遊戯論の基本スタンスを作り上げたといっても過言で はない。

ホイジンガ (Johan Huizinga, 1872-1945, オランダ の歴史・文化史家でありレイデン大学学長,『中世の秋』 が有名) は, 比較言語学, 文化史学者の視点から, 中 世から近代における遊び研究を見事に整理した人物で ある.代表的な著書『ホモ・ルーデンス (homo ludens; 遊戯的人間)』(1938)において, 遊ぶという一見不真 面目に見られる行為が，考えられているより真面目な 機能を果たしていて, 人間文化の本質と密接に関わり あっている，という問題提起をしている . 中世末期の 文化の基調とは一種の夢と遊びであり，光こで彼は遊 びの本質と光の表現形態を考察し，「遊び」は「文化」 を生みこれを支えるものであるという結論を導いてい る [6]. ホイジンガ曰く,「遊び」の形式的特徵は, ま ず「遊び」という概念が, 光れ以外のあらゆる思考形 式とは常に無関係であることを述べながら，

1. 第一に「自由な行為」である. 命令されてする遊 びはもはや遊びではない .

2.「必要」や「欲望」の直接的満足という課程の外 にある。また遊びは，この欲望の課程を一時的に 停止させる .

3. 日常生活から「場と持続時間によって区別され る」．完結性と限定性が「遊び」の特徵を形作り， 反復が可能になる .

4.ひとつの固有な「絶対的秩序」が統べている「遊 び」は秩序を創り，秩序产のものである .

5.「遊びは美しくあろうとする傾向」がある. 秩序 や緊張，リズムとハーモニーといった性質がある .

とした.もちろん, 文化史学者的視点であり, 論理的 に脆弱な点もあるが，これは「現代の遊び」において も共通な特徵として共感できる点がある.

現代に入り，カイヨワ (Roger Caillois, 1913-1978, フランスの代表的知識人といわれる思想家) は, 兴の 一生を通して「聖なるもの, 戦争, 遊びや賭け事, 夢」 といった, 人間の心を騒がせ, 魅了し, ときには隷属 させる「不可解で抗しがたい情動」についての研究を 行った . 兴の代表的著書『遊びと人間』(1958)におい て, カイヨワはシラーの預言者的直感と, ホイジンガ の『ホモ・ルーデンス』における「遊び」の理論的分 析と文明の発展における役割の重要性を(炎の著書と
しての評価を強く批判しながらも) 高く評価した上で， 遊びの体系的な分類と, 文明にどのような痕跡を残し ているか確証することを試みた . カイヨワはホイジン ガの説に対し「遊び产のもの」の叙述や分析, また賭 博やスポーツなどへの言及を避けていることを指摘し， 「遊び」についての基本定義として, 以下のようにホ イジンガの説を再定義した .

1.「自由な活動」遊戯者か強制されないこと.もし 強制されれば遊びはたちまち魅力的な愉快な楽し みという性質を失ってしまう。

2.「隔離された活動」あらかじめ決められた明確な 空間と時間の範囲内に制限されていること.

3.「未確定の活動」ゲーム展開が決定されていたり， 先に結果が分かっていたりしてはならない．創意 の必要があるのだから, ある種の自由が必ず遊戯 者の側に残されていなければならない.

4.「非生産的活動」財産も富も，いかなる種類の新 要素も作り出さないこと.(賭博のような) 遊戯者 間での所有権の移動を除いて, 勝負開始時と同じ 状態に帰着する。

5.「規則のある活動」約束ごとに従う活動 .この約 束ごとは通常法規を停止し，一時的に新しい法を 確立する．乥してこの法だけが通用する．

6.「虚構の活動」日常生活と対比した場合, 二次的 な写実，または明白に非現実であるという特殊な 意識を伴っていること．

ホイジンガに比べ, より洗練され, 整理されている といえる。しかしながら，これはあくまで形式的な特 性の列挙であり, 具体的な遊びを特定していない. 遊 びは多種多樣であり，乥れを分類する原則は難しいが， 遊びに向かう人間の「態度」は，「光の対象」によって 明らかに異なっている . 具体的には「偶然の遊び」と 「競争の遊び」である . カイヨワは，この対比に「模 擬」と「眩量 (めまい)」を加えることで, すべての遊 びは以下の 4 要素いずれかの役割が優位を占めている とした .

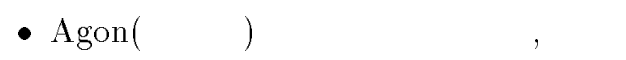

-Alea(アレア) ラテン語 : サイコロ , 賭け

- Mimicry(ミミクリ) 英語 : 真似, 模倣 , 擬態

・ $\operatorname{Ilinx}($ イリンクス) ギリシア語 : 渦巻

以下にこの 4 分類の具体的「遊び」の例を当てはめ ると,

- $\operatorname{Agon}($ 競争) : 運動競技, ボクシング, チェス

•Alea(偶然) : じゃんけん, くじ, ルーレット

- Mimicry (模擬) : 子供の物真似 (ごっこ遊び), 人 形, 仮面, 演劇

・ Ilinx(眩量) : メリーゴーランド, ブランコなど器 官の混乱と惑乱の状態を遊ぶももの 
としている.

また個々の遊びの秩序についての軸も提案し，光の 両極として , スポーツやチェスといった厳格な法規の もとで技を競う遊びである「Ludos; 闘技」と，積み木 遊びのようにルールに依存しない遊びである「Paidia; 遊戯」を提案した $[7,8]$.

カイヨワとホイジンガの研究は, この時代の特徵で ある遊びの分類化が徹底的になされている．また同時 に遊びの本質という面でもよく整理されており，現代 のエンタテイメント制作における実践の場においても 引用されることが多い著作である。

\begin{tabular}{|c|c|}
\hline $\begin{array}{c}\text { Agon } \\
\text { 〔競争〕 }\end{array}$ & $\begin{array}{c}\text { Alea } \\
\text { 〔偶然 }\end{array}$ \\
\hline $\begin{array}{c}\text { Mimicry } \\
\text { [模擬〕 }\end{array}$ & $\begin{array}{c}\text { linx } \\
\text { 〔眩暈 }\end{array}$ \\
\hline
\end{tabular}

カイヨワの4要素

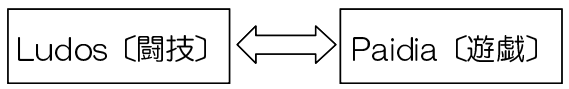

「秩序」による極

図 1: カイヨワの 4 要素と「秩序」による極

\section{3 言語的定義における問題}

エリコニンは同掲書において,「遊び」の科学的研究 における歴史的問題点についても触れている. 光も光 も「遊び」という言葉には各国語において, 複数の意 味をもっている.純粋な『楽しみ』を意味するだけで はなく「火遊び」などに使われる『戯れ』, 何かを軽率 に扱う『もてあ光ぶ』といった意味がある.また同掲書 の原著はロシア語であり，日本語には『機械工学的に， 応力を受けるべきものが受けない状態のこと』を示す 「遊び」も存在する . また古語においては, ユダヤ人は 『遊び』を「几談, 笑い」といった概念に相応させ, 古 代ローマ市民は「ludo」で「喜び，愉快」を意味した． ゲルマン人は「spilan」で「軽快な動き，弚の際に得 られる大きな満足」を意味した．乥の後，ヨーロッパ すべての言葉で「遊び」が示す言葉は人間の行為の広 い範囲を示すようになったという.つまり「遊び」と いう言葉は光の語源から，この言葉が示す厳密な意味 において, 共通した科学的概念が存在しない.この多 義性と言語的意味を明らかにしないまま, 多くの研究 者が「遊び」について共通する何かを発見しようとし たことが「遊び」の科学的研究における負の歴史を導 いたと述べている (J. コラリーの「Jeux Scientifiques; 科学的遊び批判」2).

\footnotetext{
2 Jeno Kollarits, 1870-1940,ハンガリーの精神病医「人間や動 物の広範な活動の中で, 遊びの正確な定義や境界を定めることは不 可能であり, 光のような定義の探索のすべては著者たちの『科学的 遊び (jeux scientifiques)』である」と批判した
}

同樣の言語的定義による取り組みは, 前掲書『ホモ・ ルーデンス』においてホイジンガも行っている.ホイ ジンガは比較言語学の立場から「遊び」をあらわす言 葉や炎の関連語について ,ギリシア語 , サンスクリッ 卜語, シナ語,アメリカ・インディアン語, 日本語, セ ム語, ロマン諸言語, ゲルマン諸言語等について具体 的な「遊び」を意味する言葉の有無や，弚の表現につい て述べている『ホモ・ルーデンス』のタイトルにもなっ た ${ }^{3}$ ，ラテン語における「遊び (名詞)」は「ludus」， 「遊ぶ(動詞)」は「ludo」であるが，ludosには「大競 技会」「学校」といった意味まで含まれていた。さら にludos の複合語で「風刺する alludo」「遊ぶ colludo」 「騙すilludo」といった非真実的な意味もある . ホイジ ンガは, このラテン語の「一般的遊び」の概念を示す ludo,ludos が他の初期のロマン諸言語に伝わらず, 代 わりに「冗談を言う，からかう」といった意味をもつ 「iocus(名詞),iocor(動詞)」という本来「遊び」を意味 しない言葉が光の意味範囲を拡大し, ludo,ludos を駆 逐したという.

ラテン語の iocus,iocor(ヨクス，ヨコル；ふざ

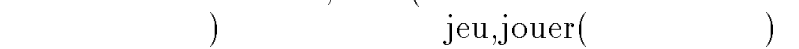
giuoco,giocare(イタリア語) , juego,jugar(スペイン 語), jogo,jogar(ポルトガル語), joc,juca(ルーマニア 語) という現在の「遊び，遊ぶ」を示す語となり，さ らに現代欧州言語では「遊び」という言葉が示す意味 に，機械装置がもつ運動に対しても光の動詞形が使用 されるようになった . ホイジンガは「遊ぶ」という概 念が, 言語的な意味では段々と拡大してきている事を 指摘している 6$]$.

ホイジンガは前掲書において，あえてラテン語の 「遊ぶ」である「ludos」を使うことで「遊び」という 言葉が持つ，原義的多義性の指摘を明らかにし，議論 の発散を回避した .また「面白さ; aardigheid(オラン ダ語), Art(ドイツ語)」という言葉を例に挙げ, 关の 意味が「あり方, 本質, 天性」であり，乥れ以上根源 的な観念に還元できないもの，どんな分析も，理論的 解釈も受け付けないものと解説した .

ホイジンガの主張は興味深いが, 本論文ではより客 観性を加えるために，身近な言語で検証してみたい． まず「面白い」という日本語は「『面 (おも) 白し』で， 目の前がぱつと明るくなる感じを表すのが原義 (三省 堂「大辞林 第二版」)」とされており, オランダ語, ド イツ語とはまったく異なる意味を持つ。

また英語の「面白い」においては，愉快を示す「fun」 と, 知的な興味についての「interesting」との違いは知 られているところであるが, interest は語源にラテン語 「inter; 中間に存在するもの」を持っている . また英語に は「楽しみ」を意味する語も複数あり「amusement」は 楽しみごと，楽しんでいる状態であり「entertainment」 は娱楽, 楽しませるもの, となっている (本論文では， 特にシステムについて扱うときは「entertainment」に 統一して使用している) .

日本語の「遊び」について，同辞典では『仕事や勉 強をせず，遊戯などをして楽しく時を過ごす』とあり 明解でないので、遊び」に関連する漢字の意味を「大

\footnotetext{
3「人類」を示す「ホモ・サピエンス (考える人 , 哲人)」に対比 させ、「モ・ルーデンス (遊引人)」とした. 本書の序説には「ホ 毛・ラァベル (作る人)」に対する考察もある。
} 
漢和辞典 (大修館書店)」において調べてみると，

-「遊」旅行する (出歩く) 友達のところへ行った り，一緒に旅行したりする、秦時與臣遊(史記)』

・「游」泳ぐ 水面を浮くようにして泳ぐこと(「泳」 は水中を潜行しておよぐこと）.

・「戯」たわむれる 動作や言葉に重点がある

・「玩」もてあ灷ぶー愛でる.よい意味と悪い意味 がある .

・「弄」たわむれる (手の動作に重点がある)

とされており，光の手段（触る, 歩く, 言葉, 移動, 泳 ぐ)や対象によって，異なる語であることが興味深い． 日本語古語について調べてみると，(1) 遊ぶこと，遊 戯，遊楽，楽しみ.(2) 音楽を奏する事. (3) 狩猟. (4) ばくち.(5)あ弚びめ (角川古語大辞典, 日本国語大辞 典等) とある. 岩波古語辞典において「遊び」は「日常 的な生活から別の世界に心身を開放し，光の中で熱中 もしくは陶酔すること」とあり，主に神楽に加え，道 具やルールに従い, 集団で巧みさを競う種の楽しみを 示している，一方「たはむれ(常軌を逸したこと，不 逞)」「あざれ (砕けた振る舞い，ふさざける)」すさび (勢いのままに荒れる，ひとりで気を紛らす)」といっ た意味を示す語も別に存在している.日常語の意味変 化辞典によると，古代の「アソブ」には「神楽を楽し む」という意味が主であり，鳥獣や魚が楽し光うに動 き回ることも「アソブ」と言ったようである . 平安時 代には詩歌，管弦，舞を楽しむの意味でよく用られ， 土地や道具などが使われていない樣子も平安時代から であるという.よ光の土地に行き，風景を楽しむ，料 亭, 遊里などで楽しむという意味, 人をからかう, 仕 事をしないでゔらら゙らするといった意味は江戶時代か らの使われ方であり，漢学の影響も読み取れる [13] .

個々の単語の意味は異なれど , ホイジンガやエリコ ニンの指摘どおり，欧州言語と同樣な多義性を確認で きるため，事前に「遊び」の定義を行わず，漠然とし た多義的な「遊び」について研究に取り組めば, 科学 的に明らかにするのは難しいといえよう.

\section{4 現代における「遊び」の研究}

中世のシラーに始まった , 非合理的な行為に見える 「遊び」を合理的な行動として理解分類する研究の流 れは, ホイジンガやカイヨワらの功績によって，現代 の「遊び」に対して，十分適用できる要素として整理 できているように見える .しかしながら, 現代科学に おいては,より実験実証的に「遊び」について語られ なければなるまい .

現代，特に第二次世界大戦後の「遊び」の科学的研 究は, 人間に関する他の科学的研究分野に分割される 傾向がある.この時代の特徵である「遊びの形態を類 型化する」という研究スタイルは変容しないが, 教育 学, 社会学, 文化民俗学といった人文科学系と, 児童 心理学や発達心理学といった認知科学, 実験的心理学 に光の場を移し，特に「観察と分析」が兴の研究の中 心となっていく.
ジャン・ピアジェ(Jean Piajet, 1896-1980, スイス の心理学者. 心理学, 論理学, 哲学, 数学教育学を学 び, 実験的臨床法により览童の知能や思考の発達過 程を研究, 知的操作の構造を明らかにした . 著諸「新 しい児童心理学」など多数)や, エリクソン (Erik H. Erikson, 1902-1994, ドイツの精神分析学者，臨床医． 同一性の理論, 心理社会的発達段階, 自我心理学の総 合者. 著書「幼児期と社会」ほか) は, 認知科学, 発 達論的視点から, 年齢を追うに従って発生する, 遊び と知性の統合的な発達の特徵を分類する『発達心理 学』の研究分野において数多くの成果を発表した.エ リコニンは前掲書『遊びの心理学』において, ヴィゴ ツキー (Vygotsuky, L.S,. 1896-1934, ソビエトの心理 学者. 生物学的, 自然主義的理論を批判し, 弁証法的 唯物論の立場に立つ新しい心理学体系の建設に多数の 理論的・実験的研究を通じて貢献をした。特に幼児や 障害児の心理や教育に注目し, 注意, 記憶, 象徵作用, 言語，思考などの高次精神機能の発達について教育の 役割を重視した研究を行った . 代表的著作『思考と言 語』，内言と外言など）の研究を扱い，「ごつこ遊び」 等における「遊び」に内在する想像, 創造性が非日常 的な営みの中に, ひとたび実用を離れ, 既存の系統学 習を加えてさらに高次元の想像を可能にするという， 相互依存的な循環過程としての統合を主張した .

特にピアジェは年齢 (period; 時期) を追うに従った 分類において, 非常に秀逸な「遊びの段階説」を打ち 立てているので, 一部抜粋する .

上記のような年齢に従って異なる遊びか現出するこ とは経験的にも理解できる現象であるが，「遊び」と 「知性」の発達を統合的に述べた点は, 弚の後の教育 学的遊戯論，発達論において重要な礎となっている. なお，ここで示される段階の生じる年齢には個人差が あるが, 各々の段階が生じる順序は一定で順序は変わ らないとされている。

これらの「遊び」に関する研究成果は, 近年の人文 科学や実験心理学の教科書や, 研究者が採用する原 型として扱われることも多い, 知能システムの研究分 野においては, マーヴィン・ミンスキー (Marvin L. Minsky, 1927-, アメリカの数学者. 人工知能の概念の 生みの親の一人. 1958 年から MIT 教授. 1960 年ご ろから人工知能研究の中心的存在として活躍を続け， 自然言語理解や場面の理解の枠組みとなる理論である 「フレーム理論」や学習機械のモデル「パーセプトロ ン」の限界に関する証明が有名）も代表的な著作『心 の社会』(1985) において，ピアジェらの実験を例とし た自らの論の弁証や, 几談を言って「遊ぶ」エージェ ントの可能性について論じている $[11,12]$.

\section{5 その他の遊び研究}

以上, 遊びの研究について, 源流から, 近代, 現代 まで概要をまとめた . 本節では, 光の他の近年の研究 である「おもちゃ」と「遊びリテーション」について 簡単に紹介する.コンピュータ等を用いたエンタテイ メントシステムに関しては後に述べる . 


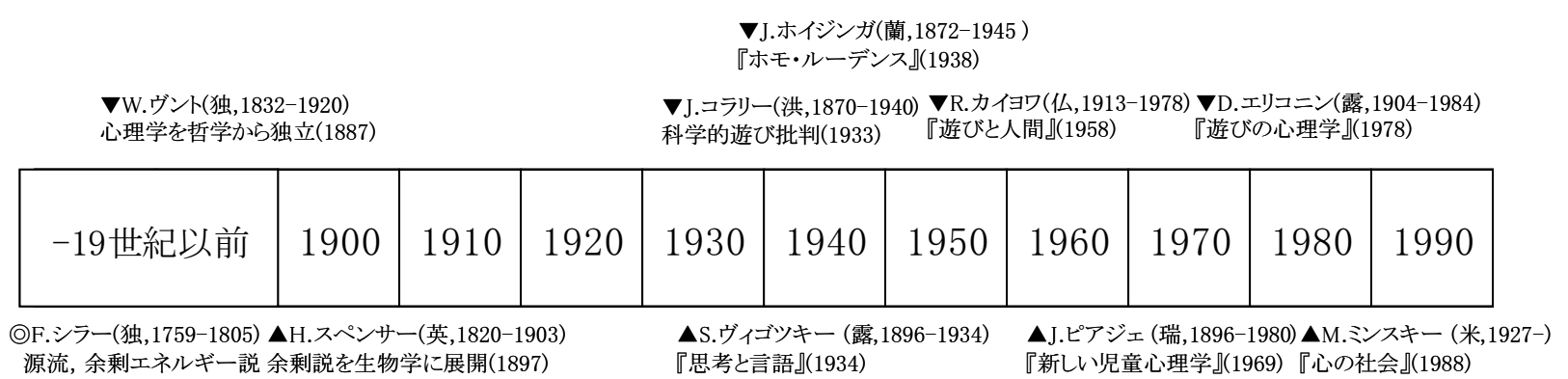

図 2:「遊び」の研究に関する主要な人物

表 1: ピアジェによる「遊びの段解説」

\begin{tabular}{|c|c|}
\hline 感覚運動遊び (sonsorimotor play) & $\begin{array}{l}\text { 生後から } 1 \text { 歳半〜2 歳ぐらいまで. } \\
\text { 感覚-運動的知能の獲得期 . }\end{array}$ \\
\hline 象徵的遊び (symbolic play) & $\begin{array}{l}2 \text { 歳〜5,6 歳まで. 記号化から言語 } \\
\text { 的想起まで. } \\
\text { ごつこ遊び, 空想 , 模倣遊びなど. }\end{array}$ \\
\hline ルールのある遊び (rule play) & $\begin{array}{l}\text { おおむね } 7 \text { 歳以降 . 思考の具体的 } \\
\text { 操作 , } \\
\text { 個人間の関係理解 , 世界観, } \\
\text { 因果と偶然が理解できる } \\
\text { ルールのある斿び，社会的遊び . }\end{array}$ \\
\hline
\end{tabular}

\subsection{1「おもちゃ」に関する研究}

日本語において「おもちゃ」はもともと「持ち遊ぶ」 という宮廷言葉が大皿化して「お」が付き「おもちゃ あ光び」になったという [15].玩具をあらわす「玩」は もとから「玩弄物」という言葉か語源であり，中国語 のくだりでも紹介したとおり「玩；もてあ光ぶ」「弄;戯 れる (手の動作)」という意味である.古くは人形遊び， 西洋源流におけるプラトンの立体「Platonic solids」 など，持って遊ぶという遊戯行動は古くから行われて いたようである .

現代の「おもちゃ」に関する研究は, 弚の産業上の 必要性から生まれるマーケティングといった統計的市 場分析だけでなく,キャラクター,コレクションといっ た社会学, 行動学的要素, プロモーションを進める上 でのメディア戦略, 教育玩具における効果, 電子おも ちゃにおけるヒューマンインタフェイス技術, 比較文 化, 民俗学など多岐にわたって产の研究的要素を提供 しつづけている.しかし同時に, 本論文でこれまで述 べてきたような「遊び」についての歴史的背景や，「遊 び」の定義を前提としない独善的，表面的，もしくは 一方的批判だけを述べる研究も多く, 本論文で引用に 值する科学的に優れたアプローチが少ないことも否定 できない. (本論文の趣旨と外れるので, 詳説は避ける が）光のような中でも, 松田, 森下らの近年の著書は 現象として変化しつづける「おもちゃ」と子供や大人 を取り巻く現象から, 社会学, 教育学的分析が深く行 われているので, 興味があれば参照されたい $[14,15]$.

\subsection{2遊びリテーション}

「遊び」を介護やリハビリテーションに取り入れ，楽 しみながら作業能力・機能回復を行おうという活動が 三好らの提案による『遊びリテーション』である [16] . 近年になって注目されている分野であるが,「レクリ エーション療法」として以前から存在していた「楽し むこと」を通した作業能力・機能回復が「目的」となっ ており，これまで述べてきた「遊び」において重要な， 自己目的性 (遊ぶこと自体が目的) や，実世界での無 利益性がなく，純粋な「遊び」とはいえない、レクリ エーション (recreation) という言葉も, 光も光も「仕 事や勉強などの疲れを癒やし, 精神的・肉体的に新し い力を盛り返すための休養・娱楽 (三省堂提供「大辞林 第二版」)」という意味であり，よく使われる用法で ある組織の連帯強化やなども含め, 純粋な意味で「遊 び」とはいえない(エデュティメント; edutainment も 教育が主目的であれば同樣といえる) .

もちろん, 機能回復や, 生きる活力を得るための効 果は注目するべきであるし，長い視点で『遊びリテー ション』によって得られる機能回復による行為谷のも のの無目的化まで含めれば，ここで扱うことができる と考えるが, 回復や訓練, 教育といった「目的を持っ た遊び」に関する研究や成果は, 作業療法, 実践教育 学等の分野で扱われるべきであって, 本論文では直接 扱わない事とする. 


\section{6 「遊び」の定義}

以上,「遊び」の科学的研究と兴の歴史について, 本 論文に関連ある事項の概要をまとめた .ここでまとめ た内容はあくまで, 中世シラーを源流とする, 近代か ら現代の原理的「遊び」研究の歴史と概要であり，現 代では純粋科学として扱われない分野も紹介した．ま た冗長を避けるために, 扱えなかつた人物や研究, 戦 争などの時代背景もあることを理解されたい .

人間はなぜ斿ゔか, なぜ面白いと感じるか，といっ た人間解明に迫る分野は, 認知科学やロボット開発と ともに, 現在も知能システム科学分野等において継続 して行われている . また扱った論の中には, 現代の技 術においてより深い追証が可能な実験もあり,「遊び」 を研究する上では, 前提として理解するべき事項が 多い。

特に,エリコニンやホイジンガが述べたとおり「遊 び」は各国語において，多くの異なる意味を持つ.よっ て研究において注目する「遊び」の定義について基本 概念を明確にする必要があると思われるので，まと めとして , 本論文における「遊び」の定義をここに定 める .

まず「遊び」とは，「遊ぶこと」关れ自身が目的とな る『自己目的的な行為』であり，以下の特徵を満たす べきである .

-「自由な活動」いつでも止められること

-「隔離された活動」日常生活と連続の場所, 時間, 行為でないこと

-「未確定の活動」遊戯者に創意や選択の自由があ ること

・「非生産的活動」現実世界に財や富を生まない こと

・「規則のある活動」遊びの世界を支える法則があ ること

・「虚構の活動」写実的でもよいが, 現実とは区別 がつくこと

ホイジンガ , カイヨワか唱えた「遊びの形式的特徵」 を基本とした . また，本論文内の用語定義として「遊 び (play)」, 上記の 6 点を満たした状態にある人間を 「遊戯者 (player)」, 遊戯者が自発的に上記 6 点を満た す状況を保つことを「遊戯状態 (playing)」と呼ぶこ とにする .

\section{3 エンタテイメント システム}

\section{1 基本概念}

ここまで, 背景として理解すべき「遊び」の科学的 研究と兴の歴史について紹介するとともに, 特に「遊 び」について, 光の『多義性』と『自己目的性』から， 本論文における光の用語定義について, カイヨワの提 案した「遊びの形式特徵」から,「遊び」が成立する条 件とともに定めた . 本章では『エンタテイメントシス

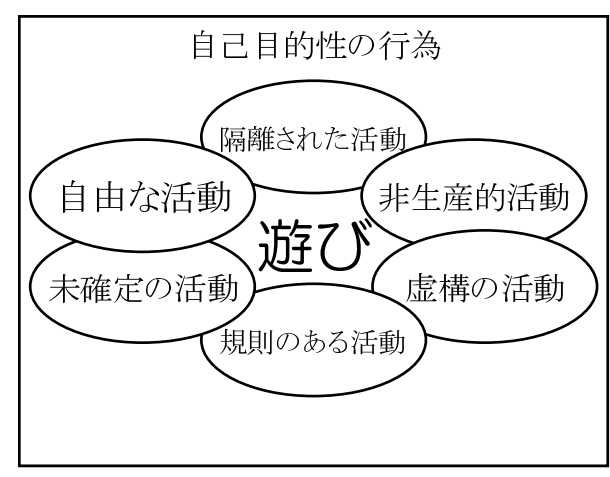

図 3:「遊び」の特性

テム (entertainment system)』についても，炎の基本 概念の定義を行いたい．

「エンタテイメントシステム」という言葉によって 扱われる範疇は広い! entertainment」とは既に述べた とおり, 余興や娱楽, 接待といった遊びや楽しみの物 的要素を広く示す語である.また「system」という語 は『個々の要素が有機的に組み合わされた, まとまり をもつ「系」』という意味であり，必ずしもコンピュー タシステムに限らない.よって「system」の語の範囲 によって，コンピュータによるエンタテイメントシス テムである「狭義の」エンタテイメントシステムと， 必ずしもコンピュータによって構筑されない「広義の」 エンタテイメントシステムが定義できるが, 光の範囲 のみの問題ともいえる.

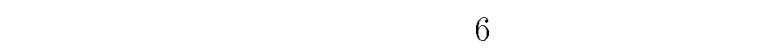
遊戯者が自発的に「遊戯状態」を保てるように設計さ れたシステムを「エンタテイメントシステム」と呼ぶ ことにする.言い換えれば, エンタテイメントシステ 么は人々が効率よく「遊戯状態」が維持できるよう， 目的を持ったシステムであるともいえる.より詳説す るために図解すると図 4 で表現できる .

まずエンタテイメントシステムには遊戯中の体験者， すなわち遊戯者 (Player) に対して「自由, 隔離, 規則, 無利益, 虚構」が維持されている必要がある.これら は前節の「遊び」の特性をもとに，よりシンプルな要 素として整理しなおしたもので，

1.「自由」強制されない, 展開が選べる，いつでも 止められること .

2.「隔離」時間, 場所において, 日常生活と隔たり があること .

3.「規則」遊びの世界を支える絶対的な法則であり， 守られる必要がある(ただし現実世界の法規は停 止する事がある) .

4.「無利益」現実世界に利益や生産物を発生させな いこと(財の移動はありえる) .

5.「虚構」写実的でもよいが, 非現実であることが わかること .

と再定義される．実際の実装上では，システムと遊戯 者の間において， 


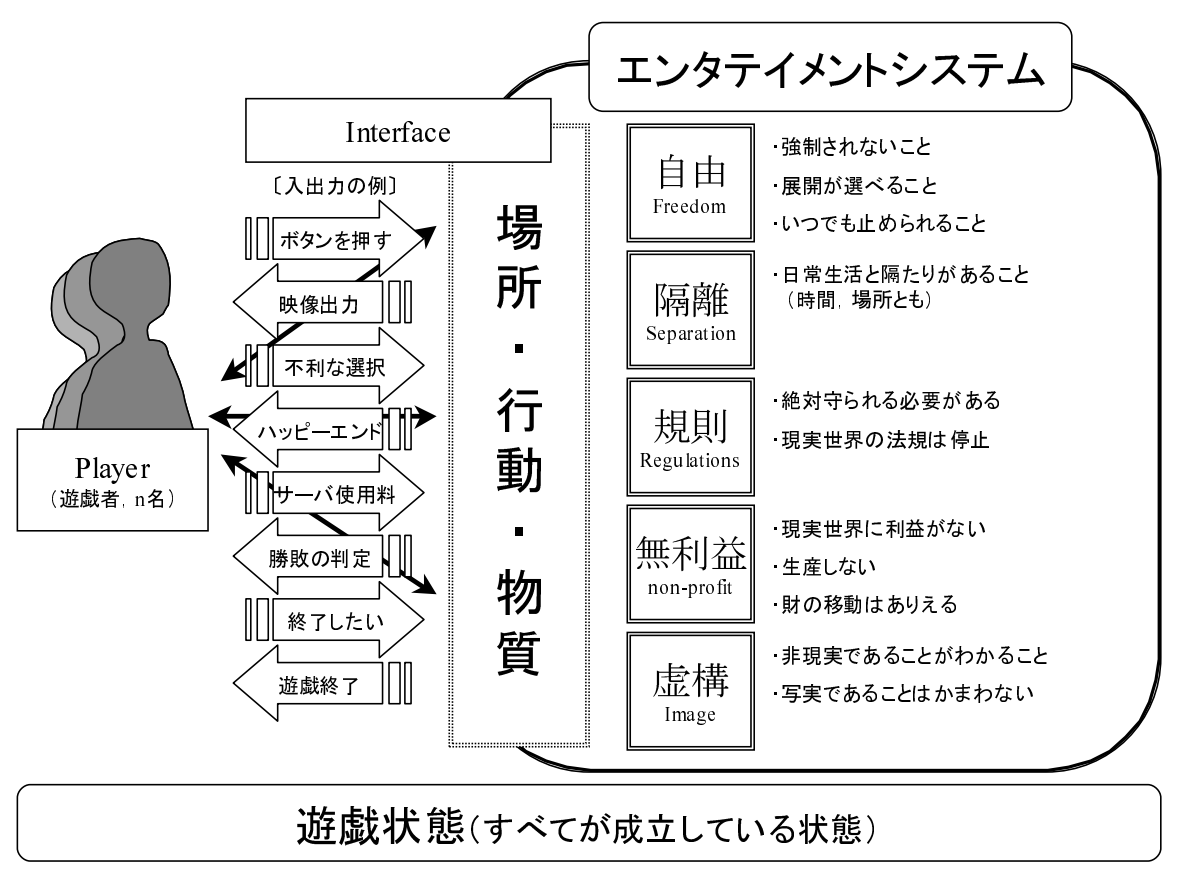

図 4: エンタテイメントシステムの定義

- 「場所」

-「行動」

-「物体」

といった界面と接点か設けられる . コントローラによ る電気的信号の入力ゃ , バーチャル世界内での「行動」 が想定されるが，これは各システムによって具現化， 実装が異なる。

\section{2 広義のエンタテイメントシステム}

ここで例として，広義のエンタテイメントシステム について例を挙げて検証してみたい .

「アミューズメントテーマパーク」というエンタテ イメントシステムは，「隔離」された「場所」ではあ るが, システム内 (パーク内) での「行動」は「自由」 である. 遊戯者は光の自発的行為によって，遊びつづ けることもできるが，止めることもできるという「自 由」も持つ.ただし，「現実」との接点は, 利用料の支 払いという「規則」があり，費やした時間や金銭に対 する「利益」や生産物はまったく存在しない．また万 有引力や疲れなどから遊戯者か開放されることはない ため, パーク内に限定された「虚構」であることは無 意識下であるが理解できる .

また別の例として「競馬運営」についても検証する． 乥も光も競馬とは軍用馬の改良のために行われた模擬 であり「虚構」の競争である . 競馬の開催は休日の競 馬場内に「隔離」されており, 遊戯者はどの馬の勝馬 投票券を購入するか「自由」である.着順と倍率によっ て配当が決定される厳格な「規則」があり, 確率の低
い勝馬の勝利を当てれば大きな配当金を手に入れるこ とができるが, 競馬運営全体においてはあらかじめ控 除率 (JRA の場合 $25 \%$ ) か設定されており, 期待值の 上でも競馬場の外に「現実的に利益を持ち出せない」 仕組みになっている . 以上のように, 競馬運営はこの 定義における広義のエンタテイメントシステムである ことを示すことができるが, どの要素が欠けても「遊 戯状態」が保てないことも想像できる.例えば「規則」 に例外を設けたり，遊戯者が賭博行為において，現実 の利益を求め「虚構」との区別がつかなくなった時か ら「遊び」は崩壊し, エンタテイメントシステムは光 の本来の目的である「遊戯状態を維持する」ことがで きなくなる ${ }^{4}$.

\section{3 エンタテイメントシステムの目的と価 値}

狭義のエンタテイメントシステムであるコンピュー タを用いたエンタテイメントシステムにおいても，コ ンテンツとハードウェアが分離可能なケースも含めて， 既に定義した 5 要素と光の自己目的性は変容しない .

「遊び」とは，乥れ自身が目的となる『自己目的性 の行為』であり目的の設定は難しいが, エンタテイメ ントシステムは光の定義から「遊戯状態を維持する」 という明確な目的 (必要条件) があるともいえる.

論理の裏を取れば，長い時間 (数分〜数年)，遊戯者 を遊戯状態にひきつけておくことができるコンピュー タシステムは, エンタテイメントシステムとして優れ 4 競馬騎手や馬主は無報酬ではないが, システムの一部であり,
賞金や利益によって年維持させる必要があり定義上問題無 
ているともいえる．つまり遊戯者がエンタテイメント システムにおいて遊技状態にあった時間は「エンタテ イメントシステムの量的価值」であると提案できる .

この定義は, コンピュータゲーム等においても個々 に成立するといえる。例えば，同一の遊戯者が，同一 のハードウェアシステムにおいて ,1100 時間で全ての シナリオを完結できるロールプレイングゲーム」と， 1 回 1 回は短い遊戯時間であるが $「 100$ 時間飽きずに 遊びつづけられるパズルゲーム」では, 遊戯者と定義 したエンタテイメントシステム間の評価として，同等 の量的価値をもつと定義づけられる.

本論文の定義では, 同一の遊戯者において, ハード ウェアシステムと自発的遊戯状態が同等の量 (時間) で あり，コンテンツのみが異なる場合にはじめて，エン タテイメントシステムの「質的価值」について評価可 能になると考える.既に行つた調査 [17]において,キー ワードの強制選択法と因子分解を用いたコンピュータ ゲームにおける興舊度の定量化とゲームジャンルの分 類を試みた . ジャンル等が確立している個々のシステ ムやコンテンツに対して, 質的価值を統計的に数值化 する事は可能であるが, 自明ではない新奇なシステム や，複合的な面白さをもつた対象に対して言語を介し て問うことは, ホイジンガらの指摘を顧みればその危 険性は明らかである .

本論文においては以上のような理由から，質的要素 については言及しない.しかしながらカイヨワの 4 要 素, 秩序による極はこの質的価值に対して分類される ものと考えられるので, 今後, 感性工学, 多変量分析 等の研究成果を期待するばかりである .

\section{4 実在の作品における検証}

前章で，本論文におけるエンタテイメントシステ ムの定義について提案を行ったが, 本章では关の検証 を, 著者か制作に関わつた実在する作品群を使って行 いたい．

\section{1「 Fantastic Phantom Slipper」}

1998 年に SIGGRAPH’98 他にて展示発表を行った , 床面利用のエンタテイメントシステムである . 遊戯者 はスリッハ型のインタフェイスを履き, プロジェクタ で床面半ドーム型スクリーンに投影されたサイバース ペースを直接歩いて遊ぶことができる．スリッパには 赤外線 LED が左右 2 点づつ実装されており, 2 次元 PSD カメラを用いて高速にベクトル動作検出を行う ことができる．また靴底には携帯電話用バイブレータ が左右 2 点ずつ実装されており，皮膚感覚における知 覚現象であるファントムセンセーションを用いて, 方 向, 距離, 強さといった多次元的振動刺激を提示する ことができる . 提示コンテンツは, 足裏におけるファ ントムセンセーションを教示的に体験できるコンテン ツ, スクリーン外から近づいてくる A.I. キャラクタ の気配をファントムセンセーションを用いて感じ取り 踏んで攻撃するコンテンツ, 足のみの操作によって空 中遊泳ができるコンテンツなどを用意し，歩いて各コ ンテンツ間のリンクを辿る事ができる.ダンスゲーム
ブーム以前であったこともあり，国籍を問わず多くの 体験者が，目と手に依存しない「体を動かす遊び」の 面白さに体験をもって興じた $[18,19]$.

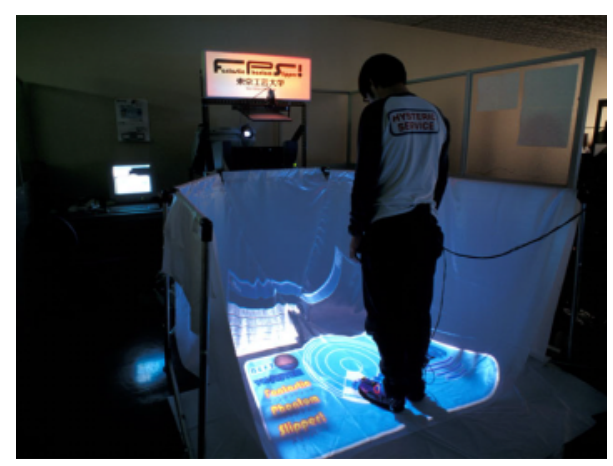

図 5: Fantastic Phantom Slipper

制作当時, 本稿におけるエンタテイメントシステム の要素については, 全く考察していなかったが, 設計 パラメータを変更することでどのように「面白さ」が 向上するかについては, 試行錯誤を繰り返していた . 以下は , 経験と主観による試行の記録である .

A.I. キャラクタを導入する以前「床面にパネルのよ うな教示をし，乥れを踏むことでダンスが踊れる」と いう設計を検討していたが，これは自由度が非常に低 く「踊って楽しむ感覚」ではなく「シシステムに踊らさ れている感覚」を覚えた。また，A.I.キャラクタの動 作アルゴリズムにおいても，当初はランダムを採用し ていたが, 皮膚刺激に対する乱数を用いた急激な変化 は不快な感覚であり, 最終的には加速度と三角関数を 用いた円運動を基本としたアルゴリズムに変更した。

また数種類のコンテンツを用意する上で, 映像の背 景か動かないよう基本的な視線べクトルは固定とした . ただし「空中浮遊」は足位置から視点位置を算出し， 弚れをもとに 3 次元視点を生成し「空を飛んでいるよ うな演出」を狙ったが, これはカイヨワの要素におけ る「Ilinx(眩量)」の強化といえよう.

\section{$4.2\lceil$ Tangible Playroom」}

2001 年以降継続して研究を行っている床面提示型 触覚エンタテイメントシステムである. 特に低年齢の 子供に向けて設計し, 未来のコンピュータエンタテイ メントシステムになるよう目指している . 子供部屋や 託児所といった, 部屋空間㚇のものをエンタテイメン 卜空間としネットワーク接続した複数のコンピュータ から床面に没入型映像投影を行う. 遊戯者は「タンジ ブルグリップ」と呼ばれる実際に把持可能な物体を握 り，部屋空間内を自由に歩き回ることができる . タン ジブルグリップにはポリエチレン製の系が取り付けら れており，壁に埋め込まれた 4 つのエンコーダモータ に繋がっている.4つのエンコーダから高速高精度に タンジブルグリップの位置を算出することができ, 同 時に適切な力覚を遊戯者にフィードバックすることが できる。 
提示コンテンツとして 3 匹の A.I. ペンギンのホッ ケーゲームに加わって遊ぶ「ペンギン・ホッケー」や， 衝突の物理のみに注目したシンプルな実験用コンテン ツなどを開発した。

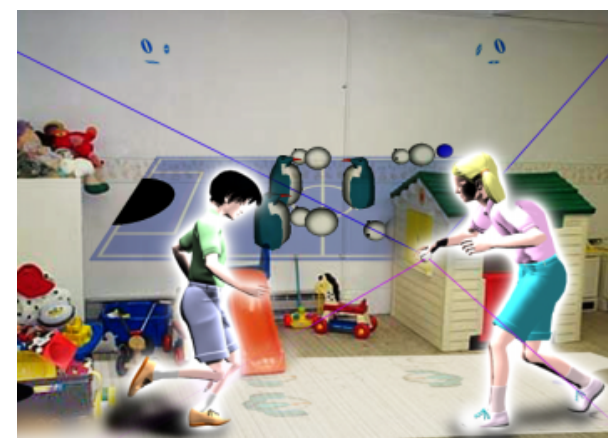

図 6: Tangible Playroom

提案したエンタテイメントシステムの定義に沿って 考察すると, 体験者は日常生活の部屋空間内で遊ぶと いう意味で隔離されていないが, タンジブルグリップ と 4 本の系を脱着させることにより，日常生活とは排 他の関係にある遊びの空間をつくりだしているという 意味で時間的に「隔離」されている．またタンジブル グリップは遊戯者の意思でいつでも把持状態を終了さ せることができ，また装着物がないので「自由」に動 き回ることができる $[20]$.

また ,コンテンツにおいても，リアルタイム物理シ ミュレータを用いた運動物理, 万有引力, ペナルティ 法による力覚フィードバックという「規則」を基本と して遊戯者を含めた全オブジェクトに働いており，A.I. キャラクタにも「興味と移動」という行動規範がある. 得点表示は行わず「無利益」である.

また , カイヨワの要素で考察すると, 没入型映像提示 は「Ilinx(眩量)」,ホッケーゲームは「Mimicry(模疑)」 であり，物理の振る舞いを触って遊ぶ行為は「Alea(偶 然)」を楽しんでいるように観察できる「Agon(競争)」 の要素は, 遊戯中において遊戯者か誰よりも速く動け る設定では強く発生しないと思われる．また秩序によ る極「Ludos(闘技) - Paidia(遊戯)」では, Paidia が 強いように思える。

\section{3「 the Labyrinth Walker」}

2002 年の SIGGRAPH 2002 Emerging Technologies にて発表したデモンストレーション作品で, 広視 野床面スクリーンと動力つきターンテーブルによる構 成で, 体験者が一切の装着物なしに, バーチャルな迷 路の世界を歩き続けることができる．床面に投影され たプロジェクタ映像の上で足踏み動作をすると，床に 埋め込まれた工業用ターンテーブルに内蔵された 4つ の感圧センサーが体験者の重心動摇を検出し, 歩行に よるステップとして認識する . また歩行の進行方向を 推定し, 体験者が気がつかないようにターンテーブル を回転させ，遊戯者をシステム正面を向かせ続けるこ
とができる . 全く装着物なしに, 無限かつ自由な方向 に歩き続けることのできる没入感覚の高いエンタテイ メントシステムである .

この『ラビリンス・ウォーカー』において，遊戯者 は「歩行すること」しかできない，展示用コンテンツ として「草原」「無限迷路」「蟻地獄」の三層に分かれ た世界を提示し，各層に存在する穴から落下すること で別の層に行くことができる.蟻地獄の穴は草原につ ながっているので, 遊戯者は無限に迷路の世界を彷得 い続けるという設計である .

なお同時期に同研究グループにおいて, 同樣の歩行 インタフェイスを用いたエンタテイメントシステムと して『vRoadRunner』か開発・発表されたが，これは レーザポインタを手にもち, 弾を発射することができ る. また映像面は壁面で, ターンテーブルを傾斜させ ることによる緩斜面の表現なども実装されていたが， 両作品とも複杂倠性は異なれどエンタテイメントシステ ムが成立していた。

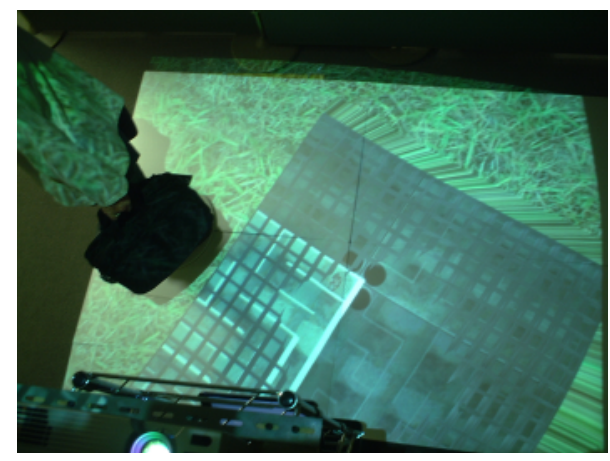

図 7: the Labyrinth Walker

提案したエンタテイメントシステムの定義に沿って 考察すると, 装着物がなく, 歩行によって自由に世界 を動くことができるため非常に「自由」度が高い「規 則」は床方向への落下と衝突のみであるが, 一貫して 守られる法則である．また遊戯者を導く「エサのよう なもの」がなくても多くの遊戯者は「無利益」の迷路 を延々と歩きつづける .このシステムにおいて「遊戯 状態」を阻害するケースは「隔離」と「虚構」を欠損 したケースであると考える.現実と虚構を「隔離」す る装着物が全くないばかりか, 「足踏み」という「虚構 の歩行」ができず, 床面スクリーンを踏み抜くケース が数名 (全体の 1 割以下であるが) 観察できた .

カイヨワの要素における分類では「Mimicry(模擬)」 と「Ilinx(眩暈)」の要素か漒いといえよう. 特に, 当 初設計になかつた「穴に落ちる」という機能を加える 前は，写実的な実写ベーステクスチャによる迷路の表 現はまさしく「模擬」であったが, 落下して他の世界 に移動できるような設計にしてからは「矓暈」の要素 を楽しむ意見が多く聞かれた (ただし, 広視野没入映 像による「酔い」を訴える遊戯者もいた）「秩序によ る極」は Paidia のようでいて, 実際には細かな歩行動 作を認識させることが難しく「相手のいないLudos」 に近いと考える。 


\section{4 アートとの境界}

エンタテイメントシステムの定義に沿って 3 作品を 考察したが, 芸術科学分野においてはメディアアート， テクノロジーアートといったアート系インタラクティ ブシステムについても検証されるべきであろう .ここ では検証を簡潔にするために，「Tangible Playroom」 で紹介したシステムと同樣のハードウェアを用いつ つ，制作意図の異なるアート作品として制作された

$\ulcorner$ Dynamo」2 作を例として挙げる .

\section{$4.5 「$ Dynamo:触れる俳句」}

$\ulcorner$ Dynamo $\lrcorner$ は, 3 自由度の空間入力・触覚提示装置で ある「デスクトップ版SPIDAR」を基盤に創られた作 品である .ソフトウェアを含め「Tangible Playroom」 と共通の技術を多く用いており，ディスプレイは底面 に設置されているが, 弚のサイズは $550 \mathrm{~mm}$ 立方と比 べて小さい .

触覚 VR 世界構築を簡易に創作できる「SPRING$\mathrm{HEAD}\lrcorner$ というソフトウェアプロジェクトの成果を利 用しており，コンテンツは基本的にテキストファイル だけで記述可能である .ソフトウェアプロジェクトの 検証をふまえた習作として「触れる俳句」は上條慎太 郎 (東京工芸大学芸術学部映像学科) が中心制作した。

舞台にはあらかじめ俳句のように五七五の韻を踏ん で配置された文字が表示されるが, これは各面に一文 字づつ五十音のひらがなが表示された立方体の積み木 であり，体験者は自由に文字列を壊し，かき混ぜ, 配 置することができる.舞台より落ちた積み木は, 延々 と画面上部より滝のように流れ落ちてくる．滝に手を 伸ばせば, 手に伝わる衝撃とともに, いくつかの積み 木を拾い上げることはできる.しかしながら落下運動 の速度は非常に速いため, 体験者の意のままに拾うこ とは難しい。

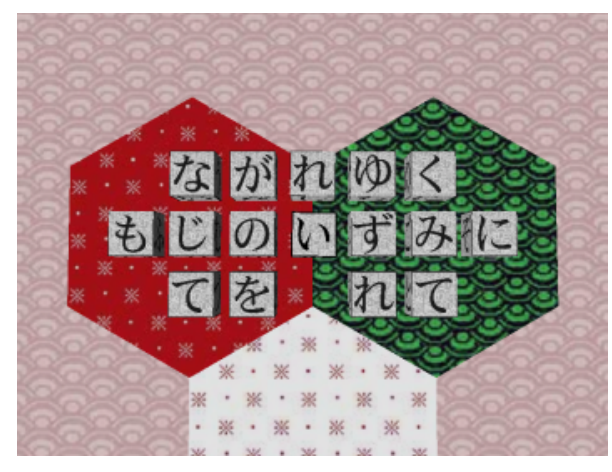

図 8: Dynamo:触れる俳句

まずこの作品をエンタテイメントシステムの定義か ら検証すると，体験者に対する「規則」が存在しない． たしかに「ペンギン・ホッケー」と同樣, 重力や衝突, 剛体の運動物理やペナルテイ法による反力は実装され ているが，体験者 (あえて遊戯者と記さない) が実行 すべき明確なタスクが存在しない.自由」度は非常
に高いが , 俳句を完成させても何かが起きるわけでは ない5 .ただし，積み木崩しや滝に手を入れたときの 感触は「興味深い」と感じるようで, これはカイヨワ の分類である「Alea(偶然)」や「Mimicry(模擬)」が， アート作品においても表出することを示していると考 察できる.

\section{6「 Dynamo:taboo」}

$\ulcorner$ Dynamo:taboo」は著者による「Dynamo」を使っ た同樣のコンテンツであり，精緻にレンダリングされ た裸体の平面 CG 映像と, SPIDAR によって接触可 能な粗い人体モデルを重ねて提示した作品である。演 出として重力と風になびく花弁を配置している.作品 は, 触覚 VR 環境において, どこまて精緻な人体が表 現可能であるか，また体験者がどのような行動を発す るか，という興味によって制作された。

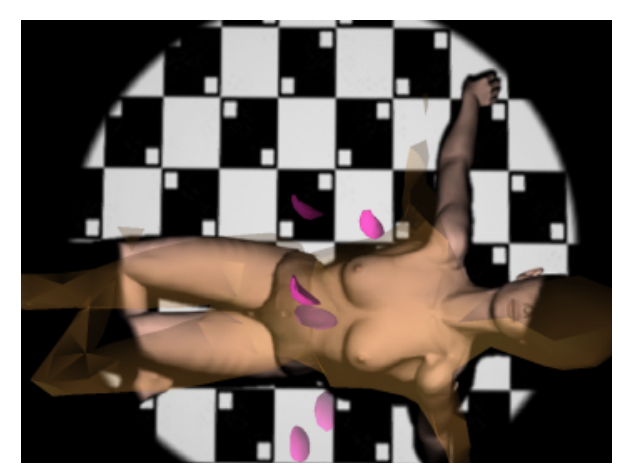

図 9: Dynamo:taboo

展示を通した観察では, 女性を中心とした多くの観 衆は, 映像があまりにリアルなためか, タンジブルグ リップの把持すら行わず，ちょつと覗き込んで立ち去 り，体験が成立していない樣子であった．また係員に よる「どう光触ってみてください」等のナビゲーショ ンを行う必要があつた。体験時間が長い体験者には中 年男性が多く, 精緻なモデリングを確認するような行 動が観察できた .また, 高速化のためにポリゴン数を 減らしたため本来の人体と異なる構造についての指摘 などを行っていた .

エンタテイメントシステムの定義に沿って考察する と「Tangible Playroom」と比較して、何をすべきか』 という体験者に対する「規則」と，映像としての「虚 構」が足りない為に「遊戯状態」にならないことが推 測できる . カイヨワの要素では「Mimicry(模擬)」が 強いといえる.仮に, エンタテイメントシステムとし て成立させるために「触ること」を明確なタスクとし て表現するために，接触時に効果音等の音声を発する よう設計すれば「虚構」としての性質も強まり『楽し い』と感じる体験者も現れるであろう．しかしながら， 弚の設計では「Dynamo:taboo」のアート作品として の作品性は失われてしまうであろう.

5 展示を通して多くの体験者から「何か起きるんですか? との 質問を受けたが, 言語解析エシジシなどは実装していない. 


\section{7 まとめ}

表 2 にこれまでの検証結果をまとめた . 提案したエ ンタテイメントシステムを構成する 5 要素に対し，光 の強さを $\{\bigcirc, \bigcirc, \triangle, \times\}$ で表現した

$\ulcorner$ Tangible Playroom」や「Dynamo」といった同樣 のシステム構成を持ったインタラクティブシステムに おいても, 要素が欠ければエンタテイメントシステム として成立しないことか読み取れる .

特に「規則」と「虚構」については午の違いが明確 に現れる．アートとは, 特にモダンアートにおいては， 自由な表現であることが多いので, 鑑賞者である体験 者にも「規則」を求めないという暗黙知があるのかも しれない．また「虚構」については,フォトリアリズ ムのような, 写実の理想を追求するアートが存在する ことからも, 必要条件として成し得ないのではないだ ろうか。

\section{5 おわりに}

本論文では, 中世から近代 , 現代の「遊び」に関する 科学的研究の歴史を紹介した上で, 近年のコンピュー タを用いた遊びのためのシステムである「エンタテイ メントシステム」の解説と定義を行った . 実在の作品 を紹介し，提案したエンタテイメントシステムの定義 の検証を通して , メディアアートやテクノロジアート といった他のインタラクティブシステムとの境界を明 確にした 。

本論文は著者の博士学位論文「床面提示型エンタテ イメントシステムの提案と開発」の一部を芸術科学会 論文誌の為に, 解説論文として再度書き起こしたもの である.また引用した内容については, 社会学や哲学， 心理学, 認知科学といった分野の専門家からみれば, あまりに古典であり, 考察や調査の浅い点もあるかも しれない．しかしながら，いまだ黎明期にあるインタ ラクティブアート, 光して「新たな面白さ」を探求し ていかねばならないコンピュータエンタテイメントに 関わる作家, 研究者, 教育者にとって，作家であり， 工学者である立場の著者がこのような解説論文を執筆 する機会を頂くことで, 今後の芸術科学分野の作品制 作, 研究活動において, 作品性・基盤技術の選定や評 価, 演出等副次的要素の明確化, 乥して未知なる創作 物の分類に寄与するものであると思い，筆を執った . 批判や異論などは甘んじて受けたい .

\section{参考文献}

[1] Ministry of Culture and Communication, France $\ulcorner$ La grotte de Lascaux $\lrcorner$, http://www.culture.gouv.fr/culture/ arcnat/lascaux/fr/

[2] H. Valladas, et al,“ Palaeolithic paintings: Evolution of prehistoric cave art" , Nature, No.413, 479 (2001).

[3] エリコニン，天野幸子, 伊集院俊隆 (訳)，1989， 『遊びの心理学』, 新読書社, $407 \mathrm{pp}$.
[4] 梅澤啓一「乳幼児期における遊びの発達メカニズ 厶」『美作女子大学・美作女子大学短期大学部紀 要』, 美作女子大学, Vol.46, pp.22-35 (2001)。

[5] Kollarits J.," Quelques considerations sur la biologie et la psychologie du jeu", Archives de Psychologie, Geneve (1940).

[6] Johan Huizinga, 1938," Homo Ludens” , (高橋 英夫訳『ホモ・ルーデンス』中公文庫,1973).

[7] Roger Caillois, 1958," Les jeux et les hommes", Gallimard.

[8] R. カイヨワ, 多田道太郎, 塚崎幹夫 (訳), 1990, 『遊 びと人間』, 講談社学術文庫 $920,389 \mathrm{pp}$.

[9] J. ピアジェ,B. イネルデ, 波多野完治 (訳)，1969, 『新しい児童心理学』, 文庫クセジュ 461 , 白水 社, 161pp.

[10] J. ピアジェ,E. H. エリクソン,et al, 2000, 『遊び と発達の心理学 心理学選書』, 黎明書房, 220 pp.

[11] Marvin Minsky, 1988," The Society of Mind " , Simon and Schuster, 336pp.

[12] Marvin Minsky, 安西 祐一郎 (訳),1990,『心の社 会』, 産業図書, $574 \mathrm{p}$.

[13] 堀井令以知 (編), 2003 『日常語の意味変化辞典』, 東京堂出版, $301 \mathrm{pp}$.

[14] 松田恵示, 2003,『おもちゃの遊びとリアル-「お もちゃ王国」の現象学一』，世界思想社，218pp.

[15] 森下みさ子,1996, 『おもちゃ革命 - 手遊びおも ちゃから電子おもちゃへ』, 岩波書店, $182 \mathrm{pp}$.

[16] 三好春樹, 下山名月, 上野文規 , 1999 『遊びリテー ション学』, 雲母書房 シリーズ 生活リハビリ講 座, $279 \mathrm{pp}$.

[17] 白井暁彦, 小池康晴, 佐藤 誠: コンピューターゲー ムの興舊度定量化 (1) 主観評価を用いたゲーム ジャンルの分類, 情報処理学会シンポジウムシ リーズ (GPW2001), Vol.2001, No.14, pp.33-40, 2002.

[18] 白井暁彦, 佐藤勝, 草原真知子, 久米祐一郎: 足 インターフェイスによる複合現実感アミューズメ ントシステム : ファンタスティックファントムス リッパ, 日本バーチャルリアリティ学会論文誌, Vol.4, No.4, PP.691-698(1999).

[19] Akihiko Shirai, Masaru Sato, Yuichiro Kume and Machiko Kusahara," Foot Interface: Fantastic Phantom Slipper”, SIGGRAPH98 - 25th International Conference on Computer Graphics and Interactive Techniques, Orlando(1998). 
表 2: 各作品における要素の強さ

\begin{tabular}{|c|c|c|c|c|c|}
\hline 作品名 & 自由 & 隔离住 & 規則 & 無利益 & 虚構 \\
\hline Fantastic Phantom & & & & & \\
\hline Slipper & $\triangle$ & (a) & 0 & $\triangle$ & (a) \\
\hline Tangible Playroom & ○ & () & () & (0) & $\bigcirc$ \\
\hline Labyrinth Walk & (a) & $\triangle$ & O & (a) & $\triangle$ \\
\hline Dynamo:触れる俳句 & (0) & (0) & $x$ & (a) & 0 \\
\hline Dynamo:taboo & 0 & (a) & $x$ & (a) & $\Delta$ \\
\hline
\end{tabular}

[20] "Penguin Hockey": A Tangible Playroom for Children, Akihiko Shirai, Shouichi Hasegawa, Yasuharu Koike and Makoto Sato, The Journal of the Society for Art and Science, Vol. 1 No. 3 pp.117-124. 2002. 